\title{
KANDUNGAN ANTOSIANIN DI DALAM MAHKOTA BUNGA BEBERAPA TANAMAN HIAS
}

\author{
Insun Sangadji ${ }^{1}$, Muhammad Rijal ${ }^{2}$, Yulli Astri $\mathrm{K}^{3}$ \\ ${ }^{1}$ Program Studi Ilmu Peternakan Unpatti Ambon \\ ${ }^{2,3}$ Program Studi Pendidikan Biologi IAIN Ambon \\ E-mail: rijal_rijal82@yahoo.co.id
}

\begin{abstract}
Abstrak: Penelitian ini menggunakan Rancangan Acak lengkap yang terdiri dari 4 perlakuan (jenis mahkota bunga) dan tiap perlakuan diulang sebanyak 4 kali, sehingga total pengamatan yaitu 16 unit pengamatan. Berdasarkan hasil penelitian dan pembahasan, maka dapat disimpulkan bahwa terdapat kandungan antosianin yaitu pelargonidin dan sianin serta perbedaan kadar antosianin di dalam bunga mawar (Rosa sherardi), kembang sepatu (Hibiscus rosa sinensis L), pukul empat (Mirabilis jalapa L.), dan rosella (Hibiscus sabdariffa L.), disebabkan beberapa faktor yaitu cahaya matahari, iklim, dan tanah dengan kadar tertinggi terdapat pada bunga pukul empat, yakni dilihat pada penyelesaian Anova Kadar antosianin signifikan karena, perlakuan dari empat jenis mahkota bunga berpengaruh nyata terhadap kadar antosianin sebagai pewarna alami.
\end{abstract}

\section{Kata Kunci: Antosianin, Mahkota Bunga, Pewarna Alami}

Warna merupakan salah satu faktor sensori yang dipakai oleh manusia untuk menilai suatu produk atau keadaan lingkungan. Khusus dalam hal makanan, warna mempunyai tempat tersendiri yang cukup penting dalam penilaian kosumen. Hasil suatu penelitian menunjukkan bahwa warna untuk makanan menempati urutan kedua dari kriteria penilaian, yaitu setelah kesegaran makanan. Selanjutnya baru diikuti oleh bau, rasa, komposisi, nilai gizi dan seterusnya. Meskipun nilai gizi makanan merupakan faktor yang amat penting, dalam kenyataannya daya tarik suatu jenis makanan lebih dipengaruhi oleh penampakan, bau dan rasanya. Warna, sebagai salah satu sifat penampakan, merupakan bagian integral dari kehidupan sehari-hari (Elfi Anis, 2010). Pengalaman kita sejak lahir telah menciptakan kebiasaan-kebiasaan untuk mengasosiasikan makanan tertentu dengan suatu warna yang khas, bahkan seringkali juga kita asosiasikan warna dengan kualitas dan sifat-sifat organoleptik.

Penelitian terdahulu menunjukkan bahwa warna makanan besar sekali pengaruhnya terhadap kesan atau persepsi konsumen terhadap bau, flavour maupun tekstur. Warna lebih besar pengaruhnya terhadap persepsi konsumen daripada bau, sekalipun flavour yang diteliti termasuk yang disukai dan produknya termasuk produk yang populer. Warna sangat mempengaruhi kemampuan konsumen untuk mengidentifikasi jenis flavor maupun kemampuannya untuk mengestimasi intensitas dan 
kualitas flavour tersebut. Warna makanan juga sering menjadi indikator cita rasa dari makanan tersebut. Berkembangnya industri pengolahan pangan menyebabkan pemakaian pewarna juga semakin meningkat, terutama jenis pewarna sintetik. Pewarna sintetik mudah diperoleh di pasaran dalam banyak pilihan, tetapi kurang aman untuk dikonsumsi karena ada yang mengandung logam berat yang berbahaya bagi kesehatan (Lailatul Isnaini, 2009).

Warna yang tampak pada makanan dikarenakan dua hal, yaitu penambahan pewarna sintetis dan karena adanya pigmen alami atau tanpa tambahan bahan dari luar. Undang-undang Pangan RI Nomor 7 Tahun 1996, tentang keamanan pangan didefinisikan sebagai kondisi dan upaya yang diperlukan untuk mencegah pangan dari kemungkinan cemaran biologis, kimia dan benda lain yang dapat mengganggu, merugikan dan membahayakan kesehatan manusia. Untuk itu diperlukan pencarian alternatif pewarna alami seperti antosianin (Elfi Anis, 2010). Antosianin merupakan antioksidan alami yang dapat mencegah penyakit kanker, jantung, tekanan darah tinggi, katarak, dan bahkan dapat menghaluskan kulit. Namun demikian, janganlah berlebihan dalam mengkonsumsi antosianin ini karena dapat menyebabkan keracunan. Berdasarkan ADI (Acceptable Daily Intake), konsumsi maksimum antosianin yang diperbolehkan per hari sebesar $0,25 \mathrm{mg} / \mathrm{kg}$ berat badan kita. Untuk antosianin banyak ditemukan pada pangan nabati yang berwarna merah, ungu, merah gelap seperti pada beberapa buah, sayur maupun umbi. Beberapa sumber antosianin telah dilaporkan seperti buah mulberry, blueberry, cherry, blackberry, rosela, kulit dan sari buah anggur. Antosianin juga terdapat pada beberapa jenis tanaman hias seperti bunga kana, bunga mawar, bunga kembang sepatu, bunga pukul empat, bunga rosella dan mahkota bunga pacar air.

Tanaman hias merupakan tanaman yang memiliki bentuk unik dan khas yang berfungsi sebagai dekorasi ataupun hiasan baik dalam ruangan maupun luar rungan. Dahulu tanaman hias merupakan tanaman yang hanya berbunga saja, namun seiring perkembangan zaman tanaman hias didefinisikan sebagai tanaman yang memiliki nilai indah baik daun, bunga, batang, buah, ranting, aroma maupun akar yang bernilai artistik atau seni. Tanaman hias sudah menjadi tren di zaman sekarang, karena selain mempercantik tempat juga memberikan udara segar di sekitarnya dan juga dapat bermanfaat dalam sumber pewarna alami. Ada beberapa jenis tanaman hias yang dimanfaatkan sebagai sumber pewarna alami yaitu, bunga mawar, kembang sepatu, bunga pukul empat, dan bunga rosella.

Mawar (Rosa sherardi) merupakan mawar jenis perdu dengan tinggi 2 meter ini berasal dari Eropa tenggara. Spesies ini mudah dikenali dari daunnya yang berbulu dan berwarna abu-abu, sementara bunganya berwarna merah tua dan sangat wangi. Rosa sherardi dikenal sebagai salah satu jenis tanaman hias yang dikenal karena keindahannya, antara lain mempunyai bunga yang kompak, menarik, dan berbunga terus-menerus. Mawar yang mempunyai banyak varietas ini akan semakin mempesona dengan kehadiran 
hibrida baru. Mawar tidak hanya dimanfaatkan sebagai tanaman hias, tapi sudah merambah kepemanfaatan bahan baku produk lain, seperti minyak wangi, air mawar (untuk penurunan panas), kosmetik, sirup, campuran teh, dan lain sebagainya. Mawar (Rosa sherardi) adalah salah satu sumber pigmen antosianin yang belum banyak dimanfaatkan. Kelemahan dari tanaman ini adalah cepat mengalami busuk setelah dipetik sehingga harus segera diproses dalam waktu 2 hari. Bagian mawar yang dapat dimakan adalah kelopak bunga disebut kaliks. Kelopak bunga mawar mengandung antosianin yang merupakan zat warna alami yang terdapat pada tumbuhan (Santi, 2009).

Kembang sepatu (Hibiscus rosa sinensis L) merupakan tanaman semak suku Marvaceae yang berasal dari asia timur dan banyak di tanam sebagai tanaman hias di daerah tropis dan subtropis. Kembang sepatu memiliki bunga besar dan berwarna merah, dimana pemanfaatan bunga kembang sepatu selain sebagai tanaman hias, bunga kembang sepatu dipercaya oleh masyarakat sebagai obat demam, batuk, sariawan, dan juga sebagai bahan pewarna tetapi belum banyak digunakan (Nurlela, 2010).

Bunga pukul empat (Mirabilis jalapa L) merupakan tanaman hias yang mudah tumbuh di halaman rumah tanpa banyak perawatan. Mirabilis jalapa L adalah anggota familia Nyctaginaceae, ordo Centrospermae. Tanaman ini mudah tumbuh di tanah yang mengandung cukup unsur hara dan terlindung dari sinar matahari. Meskipun demikian tanaman ini sering dijumpai tumbuh pada lahan kering dan terkena sinar matahari langsung. Tanaman ini dibudidayakan karena keindahan warna dan ornamentasi bunganya. Tanaman ini juga memiliki kasiat obat, meskipun masih jarang penggunaanya. Kandungan kimia yang terdapat dalam tumbuhan ini adalah saponin, lavonoida, tanin, politenol, dan flavonoida (Suhari Irianto dkk, 20009). Rosella (Hibiscus sabdariffa L.) termasuk famili Malvaceae yang merupakan tanaman tropis yang banyak tumbuh di indonesia. Kelopak bunganya biasa digunakan pada pengobatan tradisional, seperti pengobatan penyakit batuk, gangguan pencernaan, serta berpengaruh terhadap fungsi diuretik. Bunga ini mengandung gossipetin, glukosida, bibiscin, dan antosianin hibiscus. Warna merah yang bagus dan rasa yang unik menjadikan rosela sebagai produk makanan, karena berpotensi sebagai sumber pewarna makanan alami. Kelopak bunganya mengandung pigmen merah empat antosianin yakni delphinidin 3 sambubiosida, sianidin 3 sambubiosida, delphinidin 3 glukosida dan sianidin 3 glukosida (Meini Zusairi, 2009).

\section{METODE PENELITIAN}

Jenis penelitian ini deskriptif kuantitatif dengan pendekatan eksperimen laboratorium yang bertujuan untuk mengetahui kandungan dan kadar antosianin pada mawar (Rosa sherardi), kembang sepatu (Hibiscus rosa sinensis L), pukul empat (Mirabilis jalapa L.), dan rosella (Hibiscus sabdariffa L.) dengan menggunakan metode eksploratif. Penelitian ini menggunakan Rancangan Acak Lengkap yang terdiri dari 4 perlakuan (jenis mahkota bunga) dan tiap perlakuan diulang sebanyak 4 kali, sehingga 
total pengamatan dalam penelitian ini adalah 16 unit pengamatan. Adapun rancangan penelitian ini, dapat dilihat pada Tabel berikut:

Tabel 1. Rancangan Penelitian

\begin{tabular}{|l|l|l|l|l|}
\hline \multirow{2}{*}{ Perlakuan } & \multicolumn{3}{|c|}{ Ulangan } & \multicolumn{5}{|l|}{} \\
\cline { 2 - 5 } & 1 & 2 & 3 & 4 \\
\hline A1 & & & & \\
\hline A2 & & & & \\
\hline A3 & & & & \\
\hline A4 & & & & \\
\hline
\end{tabular}

Objek dalam penelitian ini adalah kandungan antosianin pada mahkota bunga (bunga mawar, kembang sepatu, bunga pukul empat, dan bunga rosella) yang diperoleh melalui metode eksploratif.

\section{Penentuan Antosianin}

Penelitian dilakukan dengan menggunakan metode kuantitatif yaitu analisis kandungan antosianin di dalam mahkota bunga beberapa tanaman hias sebagai sumber pewarna alami dengan menggunakan metode eksploratif, maka perhitungannya adalah sebagai berikut:

\section{Rumus:}

a. Penentuan intensitas warna diukur dengan rumus:

$$
\text { Intensitas warna }=\frac{\text { A X 25 }}{\text { Berat sampel }}
$$

b. Kandungan pigmen antosianin :

$$
\% \text { Antosianin }=\frac{\text { Absorbansi }}{\varepsilon \times \mathrm{L}} \times \mathrm{MW} \times \mathrm{DF} \times \frac{\mathrm{V}}{\mathrm{Wt}} \times 100 \%
$$

Keterangan:

$$
\begin{array}{ll}
\varepsilon & : \text { Absorptivitas molar sianidin } 3 \text { glukosa }=26900 \mathrm{~L}(\mathrm{~mol} . \mathrm{cm}) \\
\mathrm{L} & : \text { Lebar kuvet }=1 \mathrm{~cm} \\
\mathrm{MW} & : \text { Berat molekul sianidin } 3 \text { glukosida }=449,29 / \mathrm{mol} \\
\mathrm{DF} & : \text { Faktor pengenceran }=9 \mathrm{~mL} \\
\mathrm{~V} & : \text { Volume akhir atau volume ekstrak pigmen } 0,25 \mathrm{~L} \\
\mathrm{Wt} & : \text { Berat bahan awal }(10 \text { gram })
\end{array}
$$

\section{Ekstraksi Antosianin}

1. Menimbang mahkota bunga mawar sebanyak 10 gram, Masukan mahkota bunga mawar sebanyak 10 gram kedalam blender dan tambahkan pelarut sebanyak $250 \mathrm{~mL}$ kedalam blender dan diblender sampai halus.

2. Menimbang mahkota bunga pukul empat 10 gram, Masukan mahkota bunga pukul empat sebanyak 10 gram kedalam blender dan tambahkan pelarut sebanyak $250 \mathrm{~mL}$ kedalam blender dan diblender sampai halus.

3. Menimbang mahkota bunga kembang sepatu 10 gram, Masukan mahkota bunga kembang sepatu sebanyak 10 gram kedalam blender dan tambahkan pelarut sebanyak $250 \mathrm{~mL}$ kedalam blender dan diblender sampai halus. 
4. Menimbang mahkota bunga rosela 10 gram, Masukan mahkota bunga rosela sebanyak 10 gram kedalam blender dan tambahkan pelarut sebanyak $250 \mathrm{~mL}$ kedalam blender dan diblender sampai halus.

5. Setelah hancur dituangkan kedalam setiap wadah dan disimpan dalam lemari pendingin selama 30 menit pada suhu $10-20{ }^{0} \mathrm{C}$

6. Kemudian disentrifuse 5 menit

7. Ekstrak yang diperoleh dari ekstraksi, cara sederhana disaring dengan penyaring vakum (menggunakan kertas whatman nomor 41, guna mempercepat antara pigmen dan ampas bahan)

8. Tambahkan petroleum ether $2 \%$ untuk masing-masing ekstrak dari mahkota bunga (mawar, pukul empat, kembang sepatu, dan rosela) guna memisahkan pigmen antosianin dengan bahan pencampuran (non antosianin)

9. Warna yang ada pada petroleum ether atau filtrat antosianin, kemudian diuapkan dengan alat evaporator vakum dengan suhu $40-50{ }^{\circ} \mathrm{C}$, dilakukan pemekatan 3-5 kali.

10. Setelah pelarut diuapkan dengan evaporator vakum didapatkan ekstrak pekat.

\section{Analisis Antosianin Dengan Spektrofotometer}

1. Hasil filtrat ekstrak pekat dari bunga mawar dan tiap pengulangan dari ekstrak pekat tersebut di ukur absorbansinya dengan spektrofotometr pada panjang gelombang 510 nm.

2. Hasil filtrat ekstrak pekat dari bunga pukul empat dan tiap pengulangan dari ekstrak pekat tersebut di ukur absorbansinya dengan spektrofotometr pada panjang gelombang $510 \mathrm{~nm}$.

3. Hasil filtrat ekstrak pekat dari bunga kembang sepatu dan tiap pengulangan dari ekstrak pekat tersebut di ukur absorbansinya dengan spektrofotometr pada panjang gelombang $510 \mathrm{~nm}$.

4. Hasil filtrat ekstrak pekat dari bunga rosela dan tiap pengulangan dari ekstrak pekat tersebut di ukur absorbansinya dengan spektrofotometr pada panjang gelombang 510 nm.

\section{Penentuan Intensitas Warna}

1. Larutan buffer asam sitrat atau dibasic sodium phosphate $\mathrm{pH} 3$ disiapkan sebanyak $200 \mathrm{~mL}$ dengan cara $159 \mathrm{~mL}$ larutan asam sitrat 2,1\% dicampurkan dengan $41 \mathrm{ml}$ larutan dibasic sodium phosphate $0,16 \%$.

2. Kemudian $\mathrm{pH}$ diatur hingga $\mathrm{pH} 3$ dengan menggunakan larutan asam sitrat atau larutan dibasic sodium phosphate.

3. Panjang gelombang maksimum dari larutan diukur dengan cara sejumlah $20 \mathrm{mg}$ sampel dari ektrak pekat mahkota bunga (mawar, pukul empat, kembang sepatu, dan rosela) ditimbang. 
4. Kemudian diencerkan dalam labu ukur $25 \mathrm{ml}$ menggunakan larutan buffer asam sitratdibasic sodium phosphate $\mathrm{pH} \mathrm{3}$, setelah itu diukur absorbansinya dengan panjang gelombang $510 \mathrm{~nm}$ sehingga absorbansi yang terukur sebesar 0,2-0,7.

5. Kemudian sampel lainnya diukur absorbansinya (A) pada kuvet dengan tebal $1 \mathrm{~cm}$ menggunakan larutan buffer asam sitrat-dibasic sodium phosphate $\mathrm{pH} 3$

6. Pada panjang gelombang maksimum $510 \mathrm{~nm}$ yang telah ditentukan sehingga absorbansi yang terukur sebesar 0,2-0,7.

7. Larutan buffer asam sitrat-dibasic sodium phosphate $\mathrm{pH} 3$ digunakan sebagai blankonya.

Data penelitian yang diperoleh yaitu dengan uji pendahuluan dengan penentuan kadar senyawa antosianin pada mawar (Rosa sherardi), kembang sepatu (Hibiscus rosa sinensis L), pukul empat (Mirabilis jalapa L.), dan rosella (Hibiscus sabdariffa L.) dan uji intensitas warna pada mawar (Rosa sherardi), kembang sepatu (Hibiscus rosa sinensis L), pukul empat (Mirabilis jalapa L.), dan rosella (Hibiscus sabdariffa L.). Data yang diperoleh berupa kadar antosianin pada setiap mahkota bunga dianalisis secara deskriptif dan dengan menggunakan statistik inferensial, yaitu melakukan uji ANOVA satu jalur untuk mengetahui perbedaan kadar antosianin dari setiap mahkota bunga sampel yang diuji.

\section{HASIL DAN PEMBAHASAN}

\section{Kadar Antosianin Jenis Bunga Sebagai Pewarna Alami}

Tabel 2. Hasil Kadar Antosianin

\begin{tabular}{|c|c|c|c|c|c|c|}
\hline \multirow{2}{*}{ Perlakuan } & \multicolumn{4}{|c|}{$\begin{array}{c}\text { Kadar Antosianin } \\
(\%)\end{array}$} & \multirow{2}{*}{$\begin{array}{c}\text { Jumlah } \\
\text { (\%) }\end{array}$} & \multirow{2}{*}{$\begin{array}{c}\text { Rata-rata } \\
(\%)\end{array}$} \\
\hline & 1 & 2 & 3 & 4 & & \\
\hline $\begin{array}{c}\text { A1 } \\
\text { Kembang sepatu }\end{array}$ & 0,727 & 0,738 & 0,743 & 0,748 & 2,956 & $0,739^{a}$ \\
\hline $\begin{array}{c}\text { A2 } \\
\text { Rosela }\end{array}$ & 0,791 & 0,794 & 0,797 & 0,798 & 3,18 & $0,795^{b}$ \\
\hline $\begin{array}{c}\text { A3 } \\
\text { Mawar }\end{array}$ & 0,839 & 0,919 & 0,970 & 0,980 & 3,708 & $0,925^{\mathrm{b}}$ \\
\hline $\begin{array}{c}\text { A4 } \\
\text { Pukul empat }\end{array}$ & 0,940 & 0,980 & 0,990 & 1,000 & 3,91 & $0,977^{\mathrm{b}}$ \\
\hline
\end{tabular}

Sumber: Data Primer 2014

Nilai yang diikuti huruf tidak sama menunjukkan perbedaan nyata, dan nilai yang diikuti dengan huruf yang sama menunjukkan perbedaan tidak nyata pada taraf signifikan $5 \%,\left(\mathrm{BNT}_{0,05}=0,052, \mathrm{BNT}_{0,01}=0,073, \mathrm{KK}=4,03 \%\right)$. Berdasarkan tabel 4, terlihat bahwa kadar antosianin dari empat jenis mahkota bunga mempunyai kadar yang berbedabeda, yaitu pada bunga pukul empat 3,91 dengan rerata kadar antosianin 0,977 \%, bunga mawar 3,708 dengan rerata kadar antosianin $0,925 \%$, bunga rosela 3,18 dengan rerata 
kadar antosianin 0,795 \%, dan bunga kembang sepatu 2,956 dengan rerata kadar antosianin $0,739 \%$.

\section{Intensitas Warna Dari Jenis Bunga}

Tabel 3. Hasil Intensitas Warna

\begin{tabular}{|c|l|l|l|l|l|l|}
\hline \multirow{2}{*}{ Perlakuan } & \multicolumn{5}{|c|}{$\begin{array}{c}\text { Intensitas Warna } \\
\text { (cd) }\end{array}$} & \multicolumn{2}{|c|}{$\begin{array}{c}\text { Rata-Rata } \\
\text { (cd) }\end{array}$} & \begin{tabular}{c} 
(cd) \\
\cline { 2 - 5 }
\end{tabular} & 1 & 2 & & & \\
\hline $\begin{array}{c}\text { A1 } \\
\text { Kembang sepatu }\end{array}$ & 0,00025 & 0,00175 & 0,0045 & 0,0052 & 0,0117 & 0,0029 \\
\hline $\begin{array}{c}\text { A2 } \\
\text { Rosela }\end{array}$ & 0,0347 & 0,035 & 0,0357 & 0,0405 & 0,1459 & 0,0364 \\
\hline $\begin{array}{c}\text { A3 } \\
\text { Mawar }\end{array}$ & 0,159 & 0,1642 & 0,1702 & 0,1727 & 0,6661 & 0,1665 \\
\hline $\begin{array}{c}\text { A4 } \\
\text { Pukul empat }\end{array}$ & 0,1752 & 0,1757 & 0,1765 & 0,1775 & 0,7049 & 0,1762 \\
\hline
\end{tabular}

Sumber: Data Primer 2014

Berdasarkan tabel 3, terlihat bahwa intensitas warna empat jenis mahkota bunga mempunyai hasil yang berbeda-beda yaitu mahkota bunga pukul empat 0,7049 dengan rerata 0,1762 , mahkota bunga mawar 0,6661 dengan rerata 0,1665 , mahkota bunga rosela 0,1459 dengan rerata 0,0364 , dan mahkota bunga kembang sepatu 0,0117 dengan rerata 0,0029 .

\section{Kadar Antosianin}

Hasil analisis kadar antosianin, pada pewarna alami dari perlakuan empat jenis mahkota bunga berkisar antara 0,739\%-0,977\% dengan rerata total 0,859\%. Berdasarkan hasil analisis sidik ragam kadar antosianin menunjukkan bahwa perlakuan dari empat jenis mahkota bunga $(\mathrm{J})$ berpengaruh nyata $(\mathrm{P}>0,05)$ terhadap kadar antosianin sebagai pewarna alami. Hasil uji BNT 0,05 pada tabel 4, menunjukkan bahwa kadar antosianin terendah diperoleh pada perlakuan mahkota bunga kembang sepatu dengan nilai $0,0029 \%$ yang berbeda nyata dengan perlakuan jenis mahkota bunga yang lain yaitu mahkota bunga rosela dengan nilai 0,795 , mahkota bunga mawar dengan nilai 0,925 , dan mahkota bunga pukul empat dengan nilai 0,977 yang memperoleh kadar tertinggi. Hal ini diduga karena mahkota bunga pukul empat terdapat kandungan senyawa fitokimia yaitu flavonoida yang merupakan senyawa yang larut dalam air mengandung sistem aromatik yang terkonyugasi dan umumnya terdapat dalam tumbuhan, terikat pada gula sebagai glikosida dan aglikon flavonoid yang diduga terdapat dalam satu tumbuhan dalam beberapa bentuk kombinasi glikosida.

Antosianin yang berwarna yang terdapat dalam bunga hampir selalu disertai flavon atau flavonol. Hasil penelitian akhir-akhir ini telah membuktikan bahwa flavon merupakan kopigmen penting karena sangat diperlukan untuk menyatakan warna antosianin secara penuh dalam jaringan bunga (Harborne, 2007). Kandungan senyawa inilah yang menghasilkan kadar antosianin tertinggi pada mahkota bunga pukul empat. Untuk kadar terendah pada mahkota bunga kembang sepatu diakibatkan oleh perubahan 
kadar antosianin saat penyimpanan dimungkinkan karena reaksi kopigmentasi, dan ekstrak masih mengandung enzim polifenolase yang mengkatalis reaksi pencoklatan. Penyimpanan pada kondisi kamar mengakibatkan terjadinya perubahan intensitas zat warna yang cukup besar akibat reaksi kopigmentasi dan kerja enzim polifenolase, sedangkan penyimpanan pada kondisi dingin dapat menghambat terjadinya reaksi kopigmentasi dan reaksi pencoklatan (Jauharus dkk, 2010).

Warna alami pada empat jenis mahkota bunga yakni, mahkota bunga kembang sepatu menghasilkan warna oranye kecoklatan, mahkota bunga rosela menghasilkan warna merah tua pekat, mahkota bunga mawar yang menghasilkan warna merah pekat, dan mahkota bunga pukul empat yang menghasilkan warna merah tua pekat. Empat jenis dari mahkota bunga masing-masing mengandung kandungan antosianin yaitu pelagornidin dan sianin. Oleh karena itu, kombinasi dari antosianin inilah yang mungkin berperan pada warna merah hingga warna oranye kecoklatan dari ekstrak pekat pigmen alami empat jenis mahkota bunga. Jenis antosianin yang tersebar di dunia pertumbuhan yaitu pelargonidin berperan dalam warna oranye, oranye merah hingga merah tua, sedangkan sianin berperan dalam warna oranye merah, merah tua, merah keunguan, hingga merah kebiruan (Tensiska, 2010).

Kadar antosianin dari empat jenis mahkota bunga ini mengalami perbedaan kadar antosianin yang dikandung, karena dipengaruhi oleh faktor cahaya matahari, iklim, dan tanah. Pengaruh cahaya matahari untuk mahkota bunga pukul empat mekar hanya bisa pada pukul empat sore sesuai dengan namanya dan mendapatkan penyinaran matahari sebentar saja dibandingkan dengan mahkota bunga yang lain selalu mendapatkan sinar cahaya matahari dan mekar 24 jam sehari, bunga pukul empat tidak dapat setiap saat mekar. Menurut berbagai penelitian, gerak mekarnya bunga tersebut karena pengaruh berbagai faktor yang saling terkait, cahaya, suhu, kelembapan udara di sekitarnya. Faktorfaktor tersebut yang menyebabkan terjadinya perubahan turgor pada bunga, sehingga bunga mekar. Oleh karena itu, mahkota bunga pukul empat memiliki kadar antosianin tertinggi, karena kadar antosianin yang di peroleh dari jenis tumbuhan sangat berpengaruh pada lama pendadahan cahaya matahari. Dimana energi yang datang dari sinar matahari disebut insolasi. Insolasi ini terdiri atas sinar-sinar radiasi yang tersusun dari bermacammacam panjang gelombang. Sinar dengan panjang gelombang lebih pendek akan menghasilkan efek fitokimia tertentu dan mampu mempercepat proses oksidasi biomolekul (Jauharus dkk, 2009).

Iklim adalah keadaan rata-rata cuaca pada suatu wilayah dalam jangka waktu yang relatif lama. Iklim sangat berpengaruh terhadap kadar antosianin yang dihasilkan dari empat jenis bunga karena iklim pada setiap jenis bunga berbeda dengan mempunyai suhu udara yang berbeda pula, walaupun empat jenis bunga mahkota bunga ini tumbuh pada daerah iklim tropis. Untuk mahkota bunga pukul empat dapat tumbuh di tempat sejuk namun hanya memerlukan cahaya sedikit, dibandingkan dengan jenis mahkota bunga 
yang lain dapat hidup di tempat sejuk tetapi memerlukan sinar matahari yang cukup banyak. Tanah berpengaruh terhadap kadar antosianin karena jenis tempat tumbuh dari mahkota bunga yang diambil dari empat tempat yang berbeda yaitu Karang Panjang, Lorong Putri, Kebun Cengkeh, dan Arbes ini mempunyai jenis tanah yang berbeda yaitu: tanah yang ditumbuhi mahkota bunga mawar mempunyai struktur tanah liat yang padat dan berpasir ini diambil dari Karang Panjang yang mempunyai derajat keasaman $\mathrm{pH}$ tanah 6, tanah yang tumbuhi mahkota bunga pukul empat adalah tanah yang gembur, subur diambil dari Kebun Cengkeh dengan derajat keasaman $\mathrm{pH}$ tanah 7, tanah yang ditumbuhi mahkota bunga rosela yang diambil dari Arbes mempunyai struktur tanah liat dan padat mempunyai keasaman tanah $(\mathrm{pH})$ adalah 7 , dan tanah yang ditumbuhi mahkota bunga kembang sepatu yang diambil dari Lorong Putri mempunyai struktur tanah yang padat dengan keasamaan $\mathrm{pH}$ tanah 6 . Tanah menjadi salah satu faktor dari hasil kadar antosianin yang dihasilkan dari empat jenis mahkota bunga, karena adanya bahan-bahan organik yang terkandung dari setiap jenis mahkota bunga tersebut, sehingga kadar antosianin yang dihasilkan dari empat jenis mahkota bunga tersebut menghasilkan kadar antosianin yang berbeda. Sifat-sifat tanah dapat digambarkan dari warna tanah yang bervariasi. Warna tanah juga menentukan bahan organik yang dikandung. Jumlah tanah berwarna hitam lebih subur karena banyak mengandung bahan organik.

\section{Intensitas Warna}

Intensitas warna yaitu suatu karakteristik cahaya yang dapat diukur panjang gelombangnya, suatu zat akan berwarna jika zat tersebut melakukan absorbsi selektif sinar yang masuk dan meneruskan sebagian sinar yang tidak diabsorbsi atau sinar yang lewat. Berdasarkan hasil analisis sidik ragam kadar antosianin menunjukkan bahwa perlakuan dari empat jenis mahkota bunga $(J)$ tidak berpengaruh nyata $(\mathrm{P}<0,05)$ terhadap intensitas warna. Hal ini karena pada pengujian intensitas warna tidak signifikan, disebabkan warna pada ekstrak pekat dari mahkota bunga rosela yang dicampur dengan larutan buffer $\mathrm{pH} 3$ memiliki warna merah cerah mempunyai nilai absorbansi lebih kecil dibandingkan nilai absorbansi mahkota bunga mawar yang mempunyai warna terang, setelah diukur pada panjang gelombang maksimum.

Intensitas warna dari mahkota bunga pukul empat dengan hasil tertinggi 0,977 , mahkota bunga mawar dengan nilai 0,925, mahkota bunga rosela dengan nilai 0,795 dan mahkota bunga kembang sepatu dengan intensitas warna terendah 0,739 . Hal ini diduga karena kadar antosianin berkorelasi positif dengan intensitas warna, dimana mahkota bunga pukul empat memiliki intensitas warna yang lebih besar dan ekstrak pigmen mahkota bunga pukul empat dengan intensitas tertinggi berwarna merah dibandingkan dengan mahkota bunga mawar, bunga rosela, dan bunga kembang sepatu. Intensitas warna dari empat jenis mahkota bunga itu, mengalami perubahan warna setelah dicampurkan dengan larutan buffer $\mathrm{pH} 3$ yaitu hasilnya mahkota bunga mawar tidak berwarna, mahkota bunga pukul empat berwarna merah, mahkota bunga rosela berwarna 
merah, dan mahkota bunga kembang sepatu tidak berwarna. Warna yang ditimbulkan dari ekstrak mahkota bunga mawar dan mahkota kembang sepatu semakin memudar, karena kerusakan antosianin yang diakibatkan dekomposisi struktur pigmen yang oleh panas pada proses ekstraksi sehingga terjadi pemucatan dan menyebabkan warna semakin terang. Hal ini disebabkan adanya pengaruh $\mathrm{pH}$ terjadi karena kation flavilium yang berwarna merah berubah dari hidrat menjadi basa karbinol tidak berwarna. Warna pada $\mathrm{pH}$ rendah sebagian besar antosianin terdapat dalam bentuk kation flavilium yang berwarna merah, sedangkan senyawa basa karbinol yang tidak berwarna relatif kecil jumlahnya (Jauharun dkk, 2010).

\section{KESIMPULAN}

1. Dari hasil penelitian yang dilakukan di Laboratorium Balai Tehnik Kesehatan Lingkungan (BTKL) adanya kandungan antosianin pada setiap jenis mahkota bunga beberapa tanaman hias (bunga mawar, bunga pukul empat, bunga kembang sepatu, dan rosela) yakni pelargonidin dan sianin.

2. Kadar antosianin dari empat jenis bunga yaitu mahkota bunga kembang sepatu (Hibiscus rosa sinensis L) memiliki kadar antosianin terkecil yaitu 0,739\%, mahkota bunga rosela (Hibiscus sabdariffa L) 0,795\%, mahkota bunga mawar (Rosa sherardi) memiliki kadar antosianin 0,925\%, dan mahkota bunga pukul empat (Mirabilis jalapa) mempunyai kadar antosianin 0,977\%, dengan kadar tertinggi.

3. Kadar antosianin yang dihasilkan dari empat jenis mahkota bunga (kembang sepatu, rosella, mawar, dan pukul empat) mengalami perbedaan kadar, disebabkan oleh beberapa faktor yaitu cahaya matahari, iklim, dan tanah.

\section{SARAN}

1. Dengan adanya penelitian ini, diharapkan tanaman hias bisa dimanfaatkan masyarakat dalam bidang industri makanan sebagai pewarna alami menggantikan pewarna sintetik.

2. Dengan adanya penelitian ini, diharapkan tanaman hias dapat dibudidayakan disekitar kampus IAIN Ambon, agar dapat dimanfaatkan sebagai penelitian selanjutnya dalam pewarna alami makanan.

3. Semoga kedepannya ada penelitian lanjutan terkait dengan analisis kandungan antosianin di dalam mahkota bunga beberapa tanaman hias sebagai sumber pewarna alami dengan menggunakan jenis pelarut yang berbeda selain dari pelarut asam asetat.

4. Bagi peneliti selanjutnya yang ingin mengamati kandungan antosianin di dalam mahkota bunga beberapa tanaman hias sebagai sumber pewarna alami disarankan pengambilan sampel dapat dilakukan pada lokasi yang sama 


\section{DAFTAR PUSTAKA}

D. Santi. 2010. Mawar Budi Daya dan Pascapanen. Jakarta: Sinar Cemerlang Abadi. Elfi Anis Saati, Theovilla Rrd, Simon Bw. Aulanni'am. 2011. Optimalisasi Fungsi Pigmen Bunga Mawar Sortiran Sebagai Zat Pewarna Alami Dan Bioaktif Pada Produk Industri.Staf Pengajar Jurusan Ilmu \& Teknologi Pangan FPP, Univeritas Muhammadiyah Malang.

Harborne, J. B. 1987. Metode fitokimia: Penuntun Cara Modern Menganalisis Tumbuhan. ITB. Bandung

Irianto Suhar, Sutarno, Ahmad Dwi Setyawan. 2007. Keanekaragaman Mirabilis jalapa L. Berdasarkan Pola pita Isozim Peroksidase. Jurusan Biologi FMIPA Universitas Sebelas Maret (UNS) Surakarta.

Jauharus Sholikhin, Betty lukiati, Balqis. 2011. Analisis dan Uji Stabilitas Ekstrak Mahkota Bunga Dadap Merah (Erictrina crista-galli L). Fakultas Matematika dan Ilmu Pengetahuan Alam, Universitas Negeri Malang.

Lailatul Isnaini. 2010. Ekstrasi Pewarna Cair Alami Berantioksidan dari Rosella. Balai Pengkajian Teknologi Pertanian. Jawa Timur.

Lanny Lingga, Mawar. 2008. Jakarta: PT Gramedia Pustaka Utama

Meiny Suzery, Sri Lestari, Bambang Cahyono.2010. Penentuan Total Antosianin Dari Kelopak Bunga Rosela (Hibiscus sabdarifa L) Dengan Metode Maserasi. Jurusan Kimia Fakultas MIPA Universitas Diponegoro Semarang

Nurlela. 2011. Ekstraksi dan Uji Stabilitas Zat Warna Alami Dari Bunga Kembang Sepatu (Hibiscus rosa-sinensis L) dan Bunga Rosella (Hibiscus sabdarifa L). Fakultas Sains dan Teknologi Universitas Islam Negeri Syarif Hidayatullah. Jakarta.

Rene Nursaerah Mulki Lazuardi, 2010. Mempelajari Ekstraksi Pigmen Antosianin Dari Kulit Manggis (Garcinia mangostana L) Dengan Berbagai Jenis Pelarut. Jurusan Teknologi Pangan Fakultas Teknik Universitas Pasundan Bandung.

Ryan Moulana, Juanda, Syarifah Rohaya, Ria Rosika. 2012. Efektivitas Penggunaan Jenis Pelarut Dan Asam Dalam Proses Ektraksi Pigmen Antosianin Kelopak Bunga Rosella (Hibiscus sabdariffa L). Jurusan Teknologi Hasil Pertanian, Fakultas Pertanian, Universitas Syiah Kuala, Darussalam, Banda Aceh.

Tensiska, Een Sukarminah, Dita Natalia. 2010. Ekstraksi Pewarna Alami Dari Buah Arben (Rubus idaeus L) dan Aplikasinya Pada Sistem Pangan. Staf Pengajar Jurusan Teknologi Industri Pangan Fakultas Teknologi Industri UNPAD.

Wijayanti Puspita. 2010. Budidaya Tanaman Obat Rosella Merah (Hibiscus sabdariffa L.). Jurusan Agribisnis Agrofarmaka Fakultas Pertanian Universitas Sebelas Maret. Surakarta.

Syamsudin Hamid S.Pd. 2010. Kamus Lengkap Biologi. Jakarta: Gama Press.

Wiyarsi Antuni. 2011. Penentuan Kadar Berbagai Zat Gizi Pada Teh Bunga Sepatu. Laporan Penelitian, tidak diterbitkan. Lemlit UNY.

Zuhrotun Ade. 2009. Pemanfaatan Ekstrak Air Kelopak Bunga Rosella (Hibiscus sabdariffa L.) Fakultas Farmasi Universitas. Padjadjaran. 